\title{
intimate Partner Violence and Lifetime Trauma*
}

For many women, abuse by an adult partner is their first experience of victimization; for others, intimate partner violence occurs in the context of other lifetime trauma. A number of studies have begun to explore the link between histories of physical and sexual abuse in childhood and experiencing partner abuse as an adult. Women who are physically or sexually abused as children or who witness their mothers being abused appear to be at greater risk for victimization in adolescence and adulthood by both intimate and non-intimate perpetrators. ${ }^{1-4}$ 5, 6, 7, 8 And, women who experience adolescent IPV are more likely to experience IPV as adults. ${ }^{9}$

Studies of battered women in both clinical and shelter settings have found high rates of childhood abuse and childhood exposure to domestic violence. In a 2007 study by Kimerling et. al., women who experienced childhood physical or sexual abuse were almost 6 times more likely to experience adult physical or sexual victimization.${ }^{10}$ Across studies, the average reported rates of childhood physical abuse and childhood sexual abuse among women in intimate partner violence shelters or programs are $55.1 \%$ and $57.0 \%$ respectively. ${ }^{11}$

For women who have experienced multiple forms of victimization (e.g. childhood abuse; sexual assault; historical, cultural or refugee trauma), adult partner abuse puts them at even greater risk for developing posttraumatic mental health conditions, including substance abuse (a common method of relieving pain and coping with anxiety, depression and sleep disruption associated with current and/or past abuse). These conditions and coping strategies may, in turn, place them at risk for further abuse. ${ }^{12,13,14,15-21}$ The intersection between substance abuse and IPV is discussed in greater depth in another chapter in this textbook.

Socioeconomic factors can also expose women to victimization which compounds their risk for developing the range of mental health sequelae noted abuse. For example, low-income women (those most likely to be seen in both intimate partner violence shelters and the public mental health system) have the highest risk of being victimized throughout their lives. In one study, the lifetime prevalence of severe physical or sexual assault among very low-income women was found to be $84 \%$; $63 \%$ of those studied had been physically assaulted as children, $40 \%$ had been sexually assaulted as children, and $60 \%$ had been physically assaulted by an intimate partner. ${ }^{22}$ Similarly, studies conducted in welfare to work programs have documented lifetime rates of intimate partner abuse ranging from $55 \%$ to $65 \%{ }^{23-26}$, as opposed to rates of $20 \%$ found in random population samples. ${ }^{27}$

\footnotetext{
* This is an excerpt from Warshaw, C., Brashler, P., and Gill, J. (2009). Mental health consequences of intimate partner violence. In C. Mitchell and D. Anglin (Eds.), Intimate partner violence: A health based perspective. New York: Oxford University Press.
} 
A body of clinical literature describes the retraumatizing effects of more subtle forms of social and cultural victimization (e.g. microtraumatization or insidious trauma) due to gender, race, ethnicity, sexual orientation, disability and/or socioeconomic status). ${ }^{28,}$ 29-31 32, 33 Thus, although intimate partner violence itself is associated with a wide range psychological consequences, women living in disenfranchised communities face multiple sources of stress in addition to violence, including social discrimination, poorer health status and reduced access to critical resources, all of which can increase psychological distress. ${ }^{34,35}$ Again, many domestic violence survivors have experienced other forms of trauma, some of which may be going, that can affect their responses to current IPV.

\section{IPV and Mental Illness}

While most survivors of domestic abuse do not develop long lasting psychiatric disabilities, mental illness appears to heighten women's risk for abuse ${ }^{36,}$ 37. Poverty, homelessness, institutionalization, unsafe living conditions and dependence on caregivers exacerbate these risks, leaving individuals with psychiatric disabilities vulnerable to victimization by a range of perpetrators - within families, on the streets, in institutional and residential settings, and by intimate or dating partners. For example, a study of homeless women diagnosed with a serious mental illness found that a significant majority had been abused by a partner ( $70 \%$ had suffered physical abuse, $30.4 \%$ sexual abuse). ${ }^{38}$ Rates of physical or sexual abuse in adulthood by any perpetrator were $87 \%$ and $76 \%$, respectively. Intimate partner violence, itself, is often a precipitant to homelessness. ${ }^{22,39,40}$ Moreover, intimate partner violence presents particular risks for individuals with serious mental illness. Exposure to ongoing abuse can exacerbate symptoms and precipitate mental health crises, making it more difficult to access resources and increasing abusers' control over their lives. Stigma associated with mental illness and clinicians' lack of knowledge about IPV, reinforce abusers' abilities to manipulate mental health issues to control their partners, undermine them in custody battles and discredit them with friends, family and the courts. In a series of focus groups conducted in Chicago, DV advocates and survivors described a number of these tactics. For example, abusers use strategies such as threatening to commit and/or committing their partners to psychiatric institutions; forcing their partners to take overdoses, which are then presented as suicide attempts, and withholding psychotropic medications. Other examples include asserting that accusations of abuse are simply delusions, lying outright about their partners' behaviors and rationalizing their own (e.g., claiming their partner "needed to be restrained"). This kind of manipulation not only increases an abuser's control over his/her partner, but also can have a chilling affect on a woman's ability to retain custody of her children, which is often one motivation behind her partner's behavior. While this type of phenomenon cuts across cultures, immigrant women who are isolated and do not speak English are particularly vulnerable to this type of abuse. $^{41}$ 
Acute symptoms of mental illness can also heighten a woman's risk for victimization. ${ }^{42,36}$ Although psychiatric crises are often precipitated by recent trauma, for a woman experiencing symptoms of acute psychosis, clinicians may interpret accusations of victimization as delusions, thus leaving her vulnerable to further victimization. Women may be at particular risk for assault when experiencing cognitive or emotional difficulties associated with psychotic disorders. ${ }^{42}$ In addition, symptoms of severe trauma, such as dissociation or flashbacks, may also mimic psychotic disorders, heightening the potential for misdiagnosis and treatment that does not address underlying issues of abuse. Responses to previous trauma, such as dissociation or potentially risky coping strategies, may also increase a woman's vulnerability to abuse. ${ }^{37}$ In addition, trauma or mental illness in childhood or adolescence can disrupt key developmental processes, leaving women without the skills they need to negotiate power and decision-making in relationships. ${ }^{44}$ When having to manage without these skills is compounded by abuse in adulthood, the likelihood of having legitimate rights respected in any relationship may become even more remote. ${ }^{45} 46,47$

\section{References}

1. Lang AJ, Stein MB, Kennedy CM, Foy DW. Adult psychopathology and intimate partner violence among survivors of childhood maltreatment. Journal of Interpersonal Violence. Oct 2004;19(10):1102-1118.

2. Stermac L, Reist D, Addison M, Miller G. Childhood risk factors for women's sexual revictimization. Journal of Interpersonal Violence. 2002;17(6):647-670.

3. Wenzel SL, Tucker JS, Elliott MN, Marshall GN, Williamson SL. Physical violence against impoverished women: a longitudinal analysis of risk and protective factors. Womens Health Issues. Sep-Oct 2004;14(5):144-154.

4. Bensley L, Van Eenwyk J, Wynkoop Simmons K. Childhood family violence history and women's risk for intimate partner violence and poor health. Am J Prev Med. Jul 2003;25(1):38-44.

5. Classen CC, Palesh OG, Aggarwal R. Sexual revictimization: a review of the empirical literature. Trauma Violence Abuse. Apr 2005;6(2):103-129.

6. Cloitre M, Tardiff K, Marzuk PM, Leon AC, Portera L. Childhood abuse and subsequent sexual assault among female inpatients. J Trauma Stress. Jul $1996 ; 9(3): 473-482$.

7. Coker AL, Watkins KW, Smith $\mathrm{PH}$, Brandt HM. Social support reduces the impact of partner violence on health: Application of structural equation models.

Preventive Medicine. 2003;37(3):259-267.

8. Desai S, Arias I, Thompson MP, Basile KC. Childhood victimization and subsequent adult revictimization assessed in a nationally representative sample of women and men. Violence Vict. Dec 2002;17(6):639-653. 
9. Lindhorst $T$, Oxford $M$. The long-term effects of intimate partner violence on adolescent mothers' depressive symptoms. Soc Sci Med. Mar 2008;66(6):13221333.

10. Kimerling R, Alvarez J, Pavao J, Kaminski A, Baumrind N. Epidemiology and consequences of women's revictimization. Womens Health Issues. Mar-Apr 2007;17(2):101-106.

11. Golding JM. Unpublished manuscript. Chicago: Domestic Violence and Mental Health Policy Initiative; 2000.

12. Astin MC, Ogland-Hand SM, Coleman EM, Foy DS. Posttraumatic stress disorder and childhood abuse in battered women: Comparisons with maritally distressed women. J Consult Clin Psychol. Apr 1995;63(2):308-312.

13. Briere J, Runtz M. Symptomatology associated with childhood sexual victimization in a nonclinical adult sample. Child Abuse Negl. 1988;12(1):51-59.

14. Mowbray CT, Oyserman D, Saunders D, Rueda-Riedle A. Women with severe mental disorders: Issues and service needs. In: Levin BL, Blanch AK, Jennings $A$, eds. Women's Mental Health Services: A Public Health Perspective. Thousand Oaks, CA: Sage; 1998:175-200.

15. Bryer JB, Nelson BA, Miller JB, Krol PA. Childhood sexual and physical abuse as factors in adult psychiatric illness. Am J Psychiatry. Nov 1987;144(11):14261430.

16. Burstow B. Toward a Radical Understanding of Trauma and Trauma Work. Violence Against Women. Nov 2003;9(11):1293-1317.

17. Danieli $Y$, ed. International handbook of multigenerational legacies of trauma. New York: Plenum Press; 1998.

18. Duran B, Duran E, Yellow-Horse Braveheart M. Native Americans and the trauma of history. In: Thornton R, ed. Studying Native America: Problems and prospects in Native American Studies. Madison: University of Wisconsin Press; 1998.

19. Epstein JN, Saunders BE, Kilpatrick DG. Predicting PTSD in women with a history of childhood rape. J Trauma Stress. Oct 1997;10(4):573-588.

20. Langeland W, Hartgers C. Child sexual and physical abuse and alcoholism: a review. J Stud Alcohol. May 1998;59(3):336-348.

21. Wilsnack SC, Vogeltanz ND, Klassen AD, Harris TR. Childhood sexual abuse and women's substance abuse: national survey findings. J Stud Alcohol. May $1997 ; 58(3): 264-271$.

22. Bassuk EL, Buckner JC, Weinreb LF, et al. Homelessness in female-headed families: childhood and adult risk and protective factors. Am J Public Health. Feb $1997 ; 87(2): 241-248$.

23. Browne A. Family violence and homelessness: The relevance of trauma histories in the lives of homeless women. Am J Orthopsychiatry. Jul 1993;63(3):370-384.

24. Allard MA, Albelda R, Colten ME, Costenza C. In harm's way? Domestic violence, AFDC receipt, and welfare reform in Massachusetts. Boston: University of Massachusetts, McCormack Institute; 1997. 
25. Lloyd S. The effects of violence on women's employment. Chicago: Joint Center for Poverty Research; 1996.

26. Raphael J. Domestic violence: Telling the untold welfare-to-work story. Chicago, IL: Taylor Institute; 1995.

27. Tjaden $\mathrm{P}$, Thoennes $\mathrm{N}$. Prevalence and consequences of male-to-female and female-to-male intimate partner violence as measured by the National Violence Against Women Survey. Violence Against Women. 2000;6(2):142-161.

28. Brown LS, Root MP, eds. Diversity and complexity in feminist therapy. New York: Haworth; 1990.

29. Espin OM, Gawelek MA. Women's diversity: Ethnicity, race, class, and gender in theories of feminist psychology. In: Ballou M, Brown LS, eds. Personality and psychopathology: Feminist reappraisals. New York: Guilford; 1992:88-107.

30. Greene B. African American women. In: Comas-Diaz L, Greene B, eds. Women of color: Integrating ethnic and gender identities in psychotherapy. New York: Guilford; 1994:10-29.

31. Krieger N. Inequality, diversity, and health: thoughts on "race/ethnicity" and "gender". J Am Med Womens Assoc. Aug-Oct 1996;51(4):133-136.

32. Root MP. Women of color and traumatic stress in "domestic captivity": Gender and race as disempowering statuses. In: Marella A, Friedman M, Gerrity E, Scuffled R, eds. Ethnocultural aspects of posttraumatic stress disorder: Issues, resesarch and clinical applications. Washington, DC: American Psychological Association; 1996.

33. Weskott M. The feminist legacy of Karen Horney. New Haven: Yale University Press; 1986.

34. Ruzek SB, Olesen VL, Clarke A, eds. Women's health: Complexities and differences. Columbus: Ohio State University Press; 1997.

35. Warshaw C. Women and violence. In: Stotland NL, Stewart DE, eds. Psychological Aspects of Women's Health Care: The Interface Between Psychiatry and Obstetrics and Gynecology. 2nd ed. Washington, DC: American Psychiatric Press; 2001:477548.

36. Briere J, Woo R, McRae B, Foltz J, Sitzman R. Lifetime victimization history, demographics, and clinical status in female psychiatric emergency room patients. J Nerv Ment Dis. Feb 1997;185(2):95-101.

37. Goodman LA, Dutton MA, Harris M. The relationship between violence dimensions and symptom severity among homeless, mentally ill women. Journal of Traumatic Stress. 1997;10(1):51-70.

38. Goodman LA, Salyers MP, Mueser KT, et al. Recent victimization in women and men with severe mental illness: prevalence and correlates. J Trauma Stress. Oct $2001 ; 14(4): 615-632$.

39. Bassuk EL, Buckner JC, Weinreb LF, et al. Homelessness in female-headed families: childhood and adult risk and protective factors. Am J Public Health. Feb 1997;87(2):241-248. 
40. Caton CL, Shrout PE, Dominguez B, Eagle PF, Opler LA, Cournos F. Risk factors for homelessness among women with schizophrenia. Am J Public Health. Aug 1995;85(8 Pt 1):1153-1156.

41. Shinn M, Weitzman BC, Stojanovic D, et al. Predictors of homelessness among families in New York City: from shelter request to housing stability. Am J Public Health. Nov 1998;88(11):1651-1657.

42. Warshaw C, Moroney G, Barnes H. Report on mental health issues and service needs in Chicago-area domestic violence programs. Chicago: Domestic Violence \& Mental Health Policy Initiative; 2003.

43. Alexander MJ, Muenzenmaier K. Trauma, addiction, and recovery: Addressing public health epidemics among women with severe mental illness. In: Levin BL, Blanch AK, Jennings A, eds. Women's Mental Health Services: A Public Health Perspective. Thousand Oaks, CA: Sage; 1998:215-239.

44. Carmen EH. Inner-city community mental health: The interplay of abuse and race in chronic mentally ill women. In: Willie CV, Rieker PP, Kramer BM, eds. Mental Health, Racism and Sexism. Pittsburgh, PA: University of Pittsburgh; 1995:217236.

45. Harris M, Fallot RD, eds. Using trauma theory to design service systems. San Francisco: Jossey-Bass; 2001.

46. Friedman $\mathrm{SH}$, Loue $\mathrm{S}$. Incidence and prevalence of intimate partner violence by and against women with severe mental illness. J Womens Health (Larchmt). May 2007;16(4):471-480.

47. Gearon JS, Bellack AS. Women with schizophrenia and co-occurring substance use disorders: an increased risk for violent victimization and HIV. Community Ment Health J. Oct 1999;35(5):401-419. 